\title{
Large Animal Models of Glioma: Current Status and Future Prospects
}

\author{
WILLIAM H. HICKS ${ }^{1}$, CYLAINA E. BIRD ${ }^{1}$, MARK N. PERNIK ${ }^{1}$, ALI S. HAIDER ${ }^{2}$, AKSHARKUMAR DOBARIYA ${ }^{3}$, \\ KALIL G. ABDULLAH ${ }^{1}$, SALAH G. AOUN ${ }^{1}$, R. TIMOTHY BENTLEY ${ }^{4}$, AARON A. COHEN-GADOL ${ }^{5}$, \\ ROBERT M. BACHOO ${ }^{3}$, BRUCE E. MICKEY ${ }^{1}$, JUAN M. PASCUAL ${ }^{3}$ and TAREK Y. EL AHMADIEH ${ }^{1}$ \\ ${ }^{1}$ Department of Neurological Surgery, University of Texas Southwestern Medical Center, Dallas, TX, U.S.A.; \\ ${ }^{2}$ Department of Neurosurgery, Texas A\&M University College of Medicine, Houston, TX, U.S.A.; \\ ${ }^{3}$ Department of Neurology and Neurotherapeutics, \\ University of Texas Southwestern Medical Center, Dallas, TX, U.S.A.; \\ ${ }^{4}$ Department of Veterinary Clinical Sciences, Purdue University, West Lafayette, IN, U.S.A.; \\ ${ }^{5}$ Department of Neurological Surgery, Indiana University, Indianapolis, IN, U.S.A.
}

\begin{abstract}
Enhanced understanding of the molecular features of glioma has led to an expansion of murine glioma models and successful preclinical studies. However, clinical trials continue to have a high cost, extended production time, and low proportion of success. Studies in large-animal models of various cancer types have emerged to bridge the translational gap between in vitro and in vivo animal studies and human clinical trials. The anatomy and physiology of large animals are of more direct relevance to human disease, allowing for more rigorous testing of treatments such as surgical resection and adjuvant therapy in glioma. The recent generation of multiple porcine glioma models supports their use in high-throughput preclinical studies. The demonstration of spontaneous glioblastoma formation in canines further provides a unique avenue for the study of de novo glioma. The aim of this review was to outline the current status of large animal models of glioma and their value as a transitional step between rodent models and human clinical trials.
\end{abstract}

Advances in molecular technology have yielded an array of genetically engineered mouse models that reproduce the various

This article is freely accessible online.

Correspondence to: Tarek Y. El Ahmadieh, MD, The University of Texas Southwestern Medical Center, 5323 Harry Hines Blvd. Dallas, TX 75235, U.S.A. Tel: +1 3122211336, e-mail: telahmadieh@gmail.com

Key Words: Glioma, glioblastoma, large animal, pig, dog, nonhuman primate, review. features of glioblastoma (1). The strides made in these small animal (rodent) models have improved our understanding of this near-universally fatal disease and have led to many successes in drug therapies. These successes, however, have not been mirrored in human clinical trials, as made evident by less than $8 \%$ of recent cancer drugs proceeding beyond phase I (2). While a positive trend in the number of phase II clinical trials for glioblastoma exists, the converse is true of phase III results (3, 4). Clinical trials are resource-intense, with approved cancer therapies now lasting around 8 years and costing 1.2 billion dollars to develop (5). Indeed, the average development time from phase II to phase III is estimated to be 7.2 years in glioblastoma clinical trials (6). Since the approval of temozolomide in 2005 for the treatment of glioblastoma, there have been no approved therapies that improve overall survival $(7,8)$. The intensive nature and limited success of clinical trials highlight the need for more representative preclinical animal glioblastoma models. The present review explores the emerging evidence for reliable and reproducible large animal models of glioblastoma.

\section{Historical Perspectives}

The role of animal models in glioblastoma research, and other cancer types, has largely been twofold: One, to better understand the molecular events leading to tumorigenesis, and two, to study the effectiveness of existing and new treatment strategies. Mice have been the primary organism of preclinical animal cancer modeling, and improved outcomes in patients with cancer have been due, at least in part, to their versatility for subsequent therapeutic development. However, as we enter the next era of therapeutic development, the 
limitations of murine cancer models have sparked a search for alternative animal models, including large animal models. Large animal models overcome many of the anatomic and physiological limitations of modeling human disease in rodents. While large animal models are not intended to supplant all aspects of rodent research, they may serve as a transitional step in therapeutic development that better replicates human physiology and thus improves success in clinical trials (Figure 1) (9). The laboratory facilities required for genetic manipulation of these large animal models are not yet on par with those for mouse models; however, a growing interest in the field is expected to lead to expansion of their applicability and use (9). Common large-animal models include porcine (pig) and canine (dog) models, and, less commonly, non-human primate (NHP) models.

\section{Limitations of Murine Cancer Models}

The advantages of murine models are well documented and contributed to their establishment as the dominant preclinical animal cancer model. The small size of each organism is ideal for handling and care, lending to lower overall maintenance costs and a limited burden on individual labs and institutional housing centers (10). The rapid speed of reproduction coupled with large litter sizes is favorable for breeding and maintenance of genetically engineered mice populations (10). In addition, extensive characterization of the mouse genome has allowed for both ease and precision of genetic manipulation (10). Current molecular technology permits the spatial and temporal control of tumor formation and progression in mice, leading to tumors that better recapitulate their human counterparts (11). Logistically, mice have been an optimal organism for modeling the genetic and physiological features of cancer, but the significant difference between mice and humans contributes to their translational limitations.

On first observation, there are evident anatomical and physiological differences between humans and mice, most apparent of which is size, with humans growing to be 3,000fold larger than mice (12). The size difference is magnified for the brain, given the fact that the human brain is over 100 times larger in weight and more than 1,000 times larger in surface area and number of neurons $(13,14)$. This limitation is evident, for example, in the study of optic glioma in a mouse model of neurofibromatosis type 1 , where the optic nerve is smaller than a grain of rice, thus limiting the use of imaging and surgical techniques (9). Further, the mouse brain is lissencephalic, lacking the gyration and cortical development characteristic of humans and other large animals (15). Lastly, functional aspects arising from neural network phenomena, such as seizures or cognitive dysfunction, cannot be modeled in animals where the networks of interest are absent or not easily comparable with humans $(16,17)$. Thus, in the study of glioblastoma, well known for its infiltration of the brain parenchyma, critical anatomical differences in the organ of origin impose potentially confounding factors in preclinical investigation.

On average, humans live 30-50 times longer than mice and are known to undergo $10^{5}$ more cell divisions, thus harboring an increased risk of neoplastic transformation relative to mice (12). The short lifespan of mice further limits the development of certain types of cancer or highly penetrant cancer associated with loss of heterozygosity mutations $(12,18)$. Mice also exhibit significantly higher metabolic rates than humans, posing additional challenges to pharmacodynamic and pharmacokinetic studies (12). While drug doses can be extrapolated between mice and humans, in cancer chemotherapies with narrow therapeutic indices, the ambiguity can further contribute to limitations for phase I trials (19). In humans, the blood-brain barrier (BBB) is a major obstacle for the delivery of drugs to the central nervous system $(7,20)$. An increased proportion of neocortical astrocytes, pericyte heterogeneity, and differences in vascular anatomy between humans and mice present additional challenges to preclinical modeling (21-23). With over $80 \%$ of the mouse genome directly correlated with human orthologs, there are genetic correlates to many of the driver mutations of human cancer (24). However, there are well-documented examples of mutation resulting in different phenotypes in mice and humans. Loss of heterozygosity in the APC gene leads to invasive carcinoma in the human intestine while in mice it is associated with intestinal polyps with limited infiltration $(25,26)$. Similarly, knockout Brca1/2 mice display no cancer while this mutation is highly correlated with human breast and ovarian cancer (27).

While an extensive review of mouse models of glioma is outside the scope of this review, glioma modeling has largely been accomplished by chemically induced syngeneic or autologous transplants, human glioma xenografts, and genetically engineered models $(1,28,29)$. As future cancer chemotherapies are set to be targeted to specific molecular profiles, there is an increased need for animal cancer models that faithfully and reliably recapitulate human cancer.

\section{Large Animal Models of Glioblastoma}

Large-animal cancer models offer significant anatomical, physiological, and genetic advantages to preclinical cancer modeling. Porcine models have a long history in biomedical research, ranging from insulin production to surgical technique development, and are arguably the most evolved and versatile of the large-animal glioma models (30). The pig brain is gyrencephalic, better mirroring the convoluted surface of the human cortex, and better recapitulating tumor infiltration, drug delivery, and drug diffusion within cortical structures (Figure 2) $(13,15,31-34)$. The size of pigs also offers significant benefits for high-resolution imaging of the brain $(13,32)$. Pigs also have a relatively large litter capacity, with up to 20 offspring per year (15). In addition, pigs pose fewer ethical concerns than their canine or NHP counterparts, in part because their behavior 


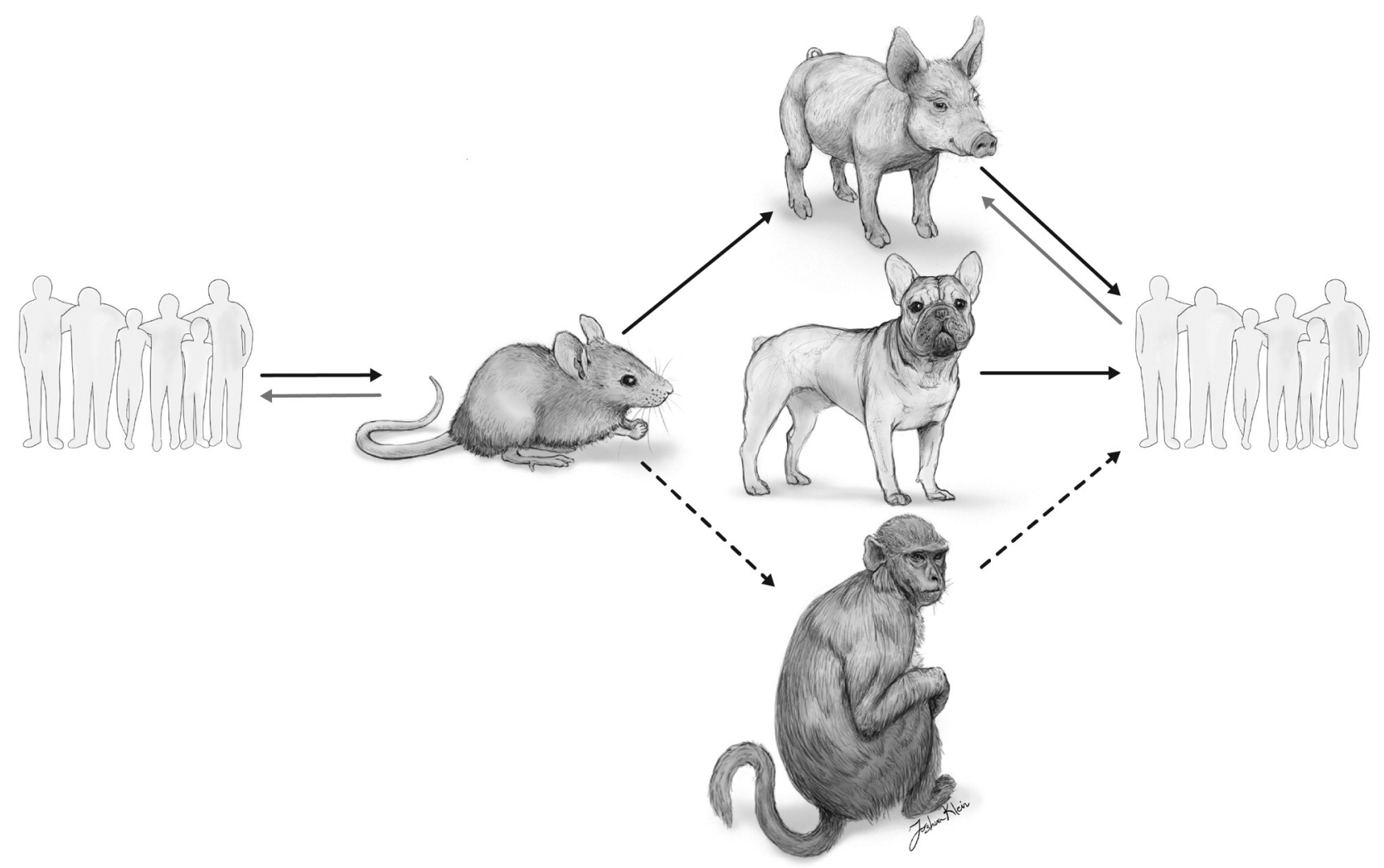

Figure 1. Proposed workflow for translational glioma research between rodent models, large animal models, and human clinical trials.

repertoire is more limited. Canines have demonstrated spontaneous formation of glioblastoma, thus offering a unique opportunity to study glioma in the absence of exogenous manipulative factors (35). NHPs are phylogenetically closer to humans and provide a high degree of similarity in terms of brain anatomy and molecular drivers of glioma-genesis (36). A discussion of NHP models is included for completeness; however, ethical considerations have limited their use as preclinical cancer models in many countries.

Porcine models. Domestic or agricultural pig breeds have long been used based on their low price and wide availability for common breeds such as the Landrace, Yorkshire, and Duroc (15). However, at mature size, pigs of these breeds weigh over $300 \mathrm{~kg}$, posing a challenge for laboratory maintenance. To overcome these limitations, minipigs such as the Yucatan, Göttingen, and Sinclair breeds have been employed (15). With a maximum size ranging from $35-90 \mathrm{~kg}$, minipig models better compare in body weight to humans and are generally favored over agricultural breeds (15). Sequencing of the genome of the domestic pig, Sus scrofa, was completed in 2012, thus expanding its applicability to biomedical and cancer research (37-40). Since then, further studies have provided the genome sequences of several laboratory pig breeds, with a profound

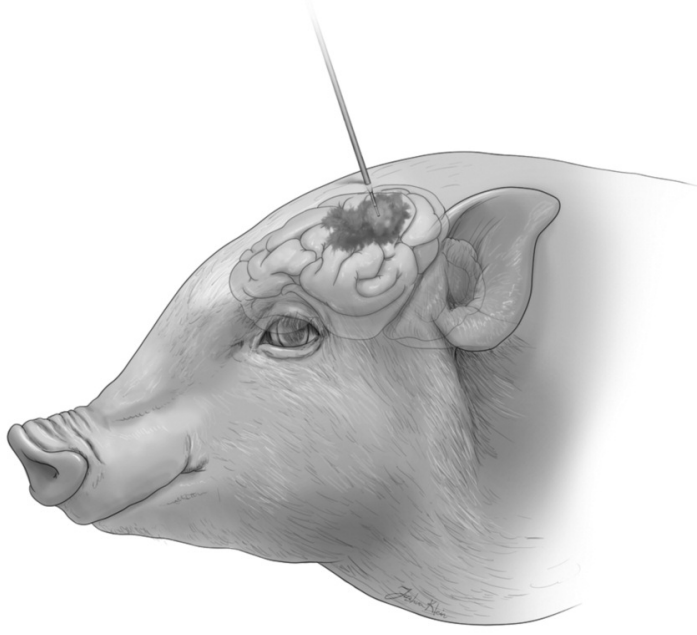

Figure 2. Porcine brain anatomy bears greater similarity to the human brain, allowing for advanced treatment approaches, ranging from surgery to convection-enhanced delivery.

impact on the development of genetically engineered porcine models $(41,42)$. More continuous and complete mapping of the porcine genome, recognition of homologous disease-linked 
Table I. Porcine models of glioma.

\begin{tabular}{lcccccc}
\hline $\begin{array}{l}\text { Type of } \\
\text { model }\end{array}$ & $\begin{array}{c}\text { Pig } \\
\text { species }\end{array}$ & Source & $\begin{array}{c}\text { Tumor } \\
\text { formation, } \mathrm{n}\end{array}$ & $\begin{array}{c}\text { Macroscopic } \\
\text { tumor }\end{array}$ & $\begin{array}{c}\text { Histopathological } \\
\text { tumor }\end{array}$ & Reference \\
\hline CLX & Landrace & U87 & $14 / 15$ & Yes & Yes & Selek et al. (2014) (47) \\
& & G6 & $1 / 5$ & Yes & Yes & Selek et al. (2014) (47) \\
& Yucatan minipig & U87 & $8 / 9$ & Yes & Yes & Khoshnevis et al. (2017) (48) \\
& & & $5 / 5$ & Yes & Yes & Khoshevis et al. (2020) (49) \\
GEM & Göttingen minipig & Lentiviral vector & $6 / 6$ & Yes & Yes & Tora (2020) (50) \\
\hline
\end{tabular}

CLX: Cell-line xenograft; GEM: genetically engineered model.

single nucleotide polymorphisms between humans and pigs, and awareness of reduced population genetic variation in pigs have further advanced these models $(30,43,44)$. Comparative analysis of the pig and human genomes revealed similarities in epigenetic regulation and gene-transcription profiles, another supporting factor for modeling human genetic diseases (45). Indeed, successful genetic engineering has developed pig models of Huntington's disease, melanoma, neurofibromatosis type 1, hepatocellular carcinoma, and adenomatous polyposis $(37-40,46)$. Thus, it is reasonable to assume glioma might be modeled in the same fashion.

To date, there are several useful porcine models for glioma (Table I). As laboratories make the appropriate accommodations for larger animals, it is anticipated that this list will continue to expand. Like humans, tumor formation in pigs is rare, and a large gap in our understanding of the natural formation of cancer in pigs is attributed to the limited lifespan that domestic breeds have before commercial utilization (9). As a result, there is no current evidence of spontaneous glioma formation in pigs.

Two distinct pig models of glioma have been developed using human cell-line xenografts (CLX). Human glioma cell lines are derived from serially maintained cultures of prior resected human glioma and are commercially available. Cell lines commonly used in xenograft models include U87, U251, T98G, and A172 $(28,29,51)$. Application of glioma CLX in pigs was first achieved when Selek et al. developed the first large-animal model of glioma (47). Utilizing 3-month-old Landrace pigs, a total of 21 animals were transplanted with U87MG (or U87) cells or G6 tumor stem cells. Given that CLX are prone to acute rejection due to immunological crossreactivity of host immunity to human cells, a prerequisite condition is an immunosuppressed host. In mice, this has been accomplished via genetically engineered immunodeficiency (52). While a pig equivalent of this model does not yet exist, Selek et al. achieved sufficient immunosuppression through oral cyclosporine (47). Of note, genetically engineered pig hearts with $\alpha 1,3$-galactosyltransferase knockout and transgenic expression of human CD46 and thrombomodulin displayed reduced immunogenicity for cardiac xenotransplantation, pointing to emerging work on this front (53). Fourteen out of fifteen U87MG recipient pigs showed macroscopic tumor formation and neurological symptoms within 30 days. Magnetic resonance imaging (MRI) of the U87MG tumors were characterized by regions of brain iso-intensity on T1and hyperintensity of T2-weighted images, consistent with human glioma (47). On histopathological analysis, the tumors displayed increased cellularity, angiogenesis, infiltration of normal brain parenchyma, and a degree of pseudo-palisading necrosis (47). On immunohistochemistry, tumor tissue stained positively for expression of glial fibrillary acidic protein (GFAP), consistent with an astrocytic character of the tumor $(54,55)$.

Soon after, Khoshnevis et al. induced the formation of glioblastoma in the Yucatan minipig via CLX of U87 cells (48). By 28 days post-induction, eight out of nine pigs displayed macroscopic tumor formation visible by computed tomography, with masses that were histopathologically indistinguishable from human undifferentiated glioma (48). One immediate application of CLX models is the ability to evaluate drugdelivery methods. Using the Yucatan minipig U87 glioblastoma model, stereotactically delivered intratumoral ${ }^{165}$ Ho-siloxane was used to assess the feasibility of microbrachytherapy, the injection of microspheres of concentrated radioactive agents, to treat glioblastoma (49). The lower average size of the Yucatan minipigs facilitated animal maintenance, lower doses of cyclosporine, and use of stereotactic frames (48). The ability to demonstrate successful glioma formation in two laboratory pig species represents a replicable model for future glioma xenograft studies.

While xenograft models allow for the assessment of tumor drug response, they pose several limitations (56). The requirement for an immunocompromised host alters the natural tumor-immune relationship and hinders the development of immunological therapy. While the BBB provides partial immunological isolation from the rest of the organism, a detailed characterization of the pig immune system and its impact on xenograft models have not been achieved (57, 58). Further, the loss of intratumoral heterogeneity arising from serial cell culture leads to cell lines that lack the genotypic and phenotypic heterogeneity of 
de novo glioma (59). Lastly, the use of established cancer cells limits study of the events leading to tumor formation and progression.

Recently, Tora $e t$ al. developed the first genetically engineered glioma model in pigs via lentiviral-induced formation of highgrade spinal cord glioma (50). In rodents, retroviral expression of platelet-derived growth factor- $\beta$, HRAS-G12V, shRNA-p53 resulted in glioma formation (60-62). Employing a similar strategy, Göttingen minipigs were injected with lentiviral vectors expressing platelet-derived growth factor- $\beta$, constitutively active HRAS, and shRNA-p53 (50). MRI of the spinal cord mass demonstrated radiological characteristics similar to those of xenografted glioma models $(47,50)$. Lesions confirmed as highgrade glioma on histopathological analysis demonstrated invasion of white and gray matter, high cellularity, elevated Ki67 expression, astrocytic morphology, and immunohistochemical evidence of GFAP and oligodendrocyte transcription factor 2 (OLIG2) expression (50). Lentiviral induction of a glioma model with multiple genetic abnormalities can be used to model the genotypic heterogeneity of glioma, allowing for the study of several common driver mutations (63). A critical advantage of a genetically engineered model is the use of an immunocompetent organism, which permits investigation of the tumor-immune relationship and the testing of immunotherapies. Application of CRISPR/Cas9 and Cre recombinase-loxP mutational methods to pigs offers another means of recapitulating the molecular features of human glioma $(18,42,64)$.

Canine models. Since the 1960s, canine models have been utilized to study cancer progression and treatment. The earliest canine studies induced malignancy in mongrel dogs using the Rous sarcoma virus or live avian sarcoma virus $(65,66)$. This created a replicable model for canine malignancies, especially astrocytoma, that could be used for treatment evaluation (65). The canine tumors created through viral induction could then be resected, frozen, reanimated, and implanted in a different mongrel dog, thus amounting to a transplantable canine cancer model (66). The transplanted canine model exhibited a 93\% tumor growth probability (66). Krisht et al. expanded this work by implanting tumors grown in nude mice derived from canine gliosarcoma cells into five immunosuppressed adult mongrel dogs, of which four developed cavernous gliosarcomas (67). While these models displayed high penetrance for tumor formation, they did not recapitulate the spontaneous tumors observed in humans. However, dogs spontaneously develop many cancer types including osteosarcoma, lymphoma, melanoma, and glioma (35). These spontaneous tumors can help to bridge the translation of findings from engineered cancer treated in murine and in vitro models to human clinical trials (5). In 2015, the National Cancer Institute's Comparative Brain Tumor Consortium was created to guide the development of new treatments for human brain tumor patients through the evaluation of canine brain tumors (68).
As in human patients, glioma is the most common primary malignant brain tumor of canines (69). Brachycephalic breeds, including Boston terriers and boxers, exhibit an elevated genetic predisposition for glioma formation and are often included in studies of these tumors (69). Canine glioblastomas display a similar histological pattern as human primary glioblastoma, including GFAP/vimentin expression, pseudopalisading necrosis, increased angiogenesis, microscopic invasion, hypercellularity, and inflammation (Figure 3) (69, 70). A comparison of the genomic profiles of canine and human glioma by Amin et al. revealed similarities in driver mutations, the timing of mutations, and epigenetic patterns of canine glioma and pediatric glioma (71). Dogs harboring brain tumors can receive treatment with maximal surgical resection followed by adjuvant therapy. As with humans, survival for dogs with glioma is dependent on the extent of resection, with longer survival for dogs with gross total resection as compared to those with subtotal or no resection (72). Canines with glioma exhibit 1-to 2-month survival without treatment (69). Thus, they can be used to test therapies before human trials (Figure 1). Dickinson et al. utilized spontaneous canine gliomas to evaluate convection-enhanced delivery of liposomal irinotecan, a topoisomerase I inhibitor, and gadoteridol in nine dogs with grade 2 or 3 gliomas (73); $88 \%$ of those tumors exhibited a post-treatment decrease in volume and demonstrated the importance of monitoring with MRI while performing convection-enhanced delivery (73). The ability of minicells containing doxorubicin to cross the BBB and selectively infect glioma tumor cells while sparing systemic toxicity has been evaluated in dogs with spontaneous glioma (74). This led to a phase I human clinical trial in Australia and the USA (75). Application of the workflow from mice to a large-animal model was seen with pharmacological testing of nanoparticle delivery of immune-modulatory microRNA to a canine model following successful trials in mice (76).

The principal benefit of studying spontaneous canine tumors is their ability for significant, natural tumor growth during a reasonable time period and the feasibility of treating in a multistep fashion under conditions similar to human tumors (73). Another value of the canine model is the heterogeneity that mimics that seen in human patients. There is inter-patient heterogeneity, as dogs of varying ages and breeds develop different types (i.e., oligodendroglioma, astrocytoma) and grades of glioma in diverse brain locations, each having different immunological and genetic profiles (77, 78). There is also intra-patient heterogeneity, as spontaneous canine glioblastoma exhibits pleomorphic cells, necrosis, vascular proliferation, and pseudo-palisading that is seen in human glioblastoma but not in murine xenografts (77). While spontaneous canine gliomas are useful during advanced stages of testing for novel therapies, they are not as useful for the characterization of the effect of single mutations on glioma-genesis, which is better accomplished in genetically 


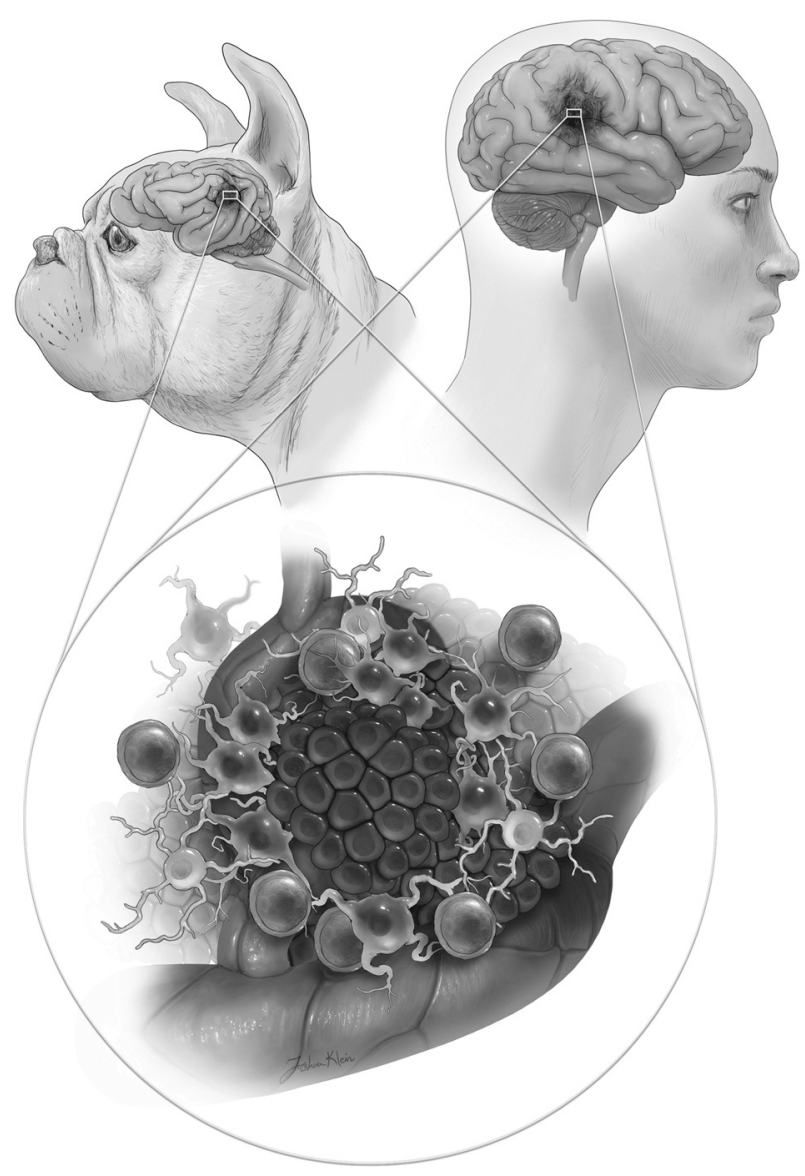

Figure 3. Histopathological and immune microenvironment similarities between de novo canine and human glioma open opportunities for immunological studies that are not feasible with other animal models.

engineered mouse models (77). Another limitation of these models is the genetic makeup of common companion dogs. Some outbred dogs, such as those with a mixed background, better replicate the diverse genetic background characteristic of humans, while inbred dogs often lack genetic diversity (5). Experimental sample size can also be a limitation for these studies given that only 12,000 dogs will develop detectable brain tumors annually in the USA and a minimum of 18-20 has been proposed as the sample size necessary for testing in canine clinical trials (77). The limited numbers available and the requirement for reagents suitable for canines limit the feasibility of these studies (79). An additional limitation for natural history and treatment studies is the practice of early euthanasia at different stages after symptoms develop (72, 79). The performance of neurological examinations by veterinary neurologists combined with serial MRI monitoring can allow objective quantification of progression-free survival, which unlike overall survival is not affected by euthanasia (80).
Non-human primate models. NHPs are attractive models for studying human disease because they are the most physiologically, anatomically, and genetically similar animals to humans, and therefore may best recapitulate tumor behavior and therapeutic responsiveness $(36,81)$. Indeed, there is a near 1:1 homology between NHP and human genomes (36). Nevertheless, studies in NHP models of cancer have been limited primarily to case reports and series of incidentally discovered tumors (82-85). One case series studied radiation-induced glioblastoma in Macaca mulatta (rhesus macaque) $(86,87)$. Lonser et al. demonstrated that after fractionated whole-brain radiotherapy (3,500 cGy over 2 weeks), a majority of $M$. mulatta developed glioblastoma between 2.9 and 8.3 years after radiotherapy (86). These tumors exhibited histological and genomic characteristics similar to de novo human glioblastoma (86). In a follow-up study, tumors in these animals with multiple glioblastomas likely arose from distinct precursor cells (87). Furthermore, primates that did not develop glioblastoma had histological evidence of atypical tumor precursor cells without common glioblastoma biomarkers (87). Together, these studies demonstrated that it was possible to model radiation-induced glioblastoma in $M$. mulatta after whole-brain radiation despite a highly variable time range of tumorigenesis (86, 87). The long latency period before apparent tumorigenesis may limit its utility to inform clinical trials. Nevertheless, this model can prove useful to study the pharmacokinetics and pharmacodynamics of potential glioma chemotherapies (88). However, BBB integrity may not recapitulate drug cerebrospinal fluid penetration in the disrupted blood-tumor barrier typical of glioma (20).

A lentiviral-induced glioblastoma model in Tupaia belangeri (tree shrew) was achieved via lentiviral-mediated overexpression of $H$-Ras and silencing of Tp53 and is characterized by mesenchymal subtype glioblastoma (89). This glioblastoma displayed classic histological features of high-grade gliomas together with greater genetic similarity to human glioblastoma as compared to mesenchymal mousederived glioblastoma (89). Notably, there was a $100 \%$ success rate of glioblastoma formation and onset of neurological symptoms as early as 1 month after lentiviral injection (89). The phylogenetic classification of $T$. belangeri has been debated, with evidence supporting a closer association with primates than previously thought and other studies reporting the contrary $(90,91)$. Nonetheless, it provides another possible model for large-animal glioma modeling.

NHP models are limited by the associated ethical considerations. It has been argued that the study of NHPs is justified and necessary due to their homology with humans, while others view it as unnecessary due to the lack of significant scientific discovery arising from use of these models (92). The primary consideration when initiating research with NHPs is the potential for benefit to humans. However, as with 
most novel scientific approaches and with hypothesis-driven research, the value of the research is not a priori predictable. The debate and controversy around NHP research have led to the reduction of NHP use in the United States and European Union $(93,94)$. With now widely available genome-editing technologies, the limited progress made in glioblastoma has raised interest in their use in NHPs (95).

\section{Conclusion}

As the need for effective glioma treatments remains unmet, attention has been turned to the development of more informative preclinical animal cancer models. In recent years, reproducible models of glioma have been developed in pigs using human xenografted glioma cell lines and lentiviral vector induction. Canines are shown to spontaneously develop glioblastoma, however, the relative rarity of this occurrence and lack of experimental reproducibility hinders its use. The use of NHPs, while likely to be most genotypically and phenotypically similar to humans, is limited by ethical considerations. Thus, based on the current evidence, porcine glioma models appear to be the most developed and promising of the preclinical large-animal models. The study of xenograft and genetically engineered porcine models offer a potential tool of investigation to overcome the poor translational outcomes of human clinical trials.

\section{Conflicts of Interest}

The Authors have no conflicts of interest to declare.

\section{Authors' Contributions}

Conceptualization, TYEA; Data curation, WHH, MNP, CEB, TYEA; Writing original draft preparation, WHH, MNP, CEB; Writing review and editing, WHH, MNP, CEB, ASH, AD, KGA, SGA, RTB, AAC, RMB, BEM, JMP, TYEA. All Authors have read and agreed to the published version of the article.

\section{Acknowledgements}

The Authors would like to thank Josh Klein for the illustration of the figures.

\section{References}

1 Hicks WH, Bird CE, Traylor JI, Shi DD, El Ahmadieh TY, Richardson TE, McBrayer SK and Abdullah KG: Contemporary mouse models in glioma research. Cells 10(3): 712, 2021. PMID: 33806933. DOI: 10.3390/cells10030712

2 Mak IW, Evaniew N and Ghert M: Lost in translation: animal models and clinical trials in cancer treatment. Am J Transl Res 6(2): 114-118, 2014. PMID: 24489990.

3 Mandel JJ, Yust-Katz S, Patel AJ, Cachia D, Liu D, Park M, Yuan Y, Kent TA and de Groot JF: Inability of positive phase II clinical trials of investigational treatments to subsequently predict positive phase III clinical trials in glioblastoma. Neuro Oncol 20(1): 113-122, 2018. PMID: 29016865. DOI: 10.1093/ neuonc/nox 144

4 Cihoric N, Tsikkinis A, Minniti G, Lagerwaard FJ, Herrlinger U, Mathier E, Soldatovic I, Jeremic B, Ghadjar P, Elicin O, Lössl K, Aebersold DM, Belka C, Herrmann E and Niyazi M: Current status and perspectives of interventional clinical trials for glioblastoma - analysis of ClinicalTrials.gov. Radiat Oncol 12(1): 1, 2017. PMID: 28049492. DOI: 10.1186/s13014-016-0740-5

5 Schachtschneider KM, Schwind RM, Newson J, Kinachtchouk N, Rizko M, Mendoza-Elias N, Grippo P, Principe DR, Park A, Overgaard NH, Jungersen G, Garcia KD, Maker AV, Rund LA, Ozer H, Gaba RC and Schook LB: The Oncopig Cancer Model: An innovative large animal translational oncology platform. Front Oncol 7: 190, 2017. PMID: 28879168. DOI: 10.3389/fonc.2017.00190

6 Vanderbeek AM, Rahman R, Fell G, Ventz S, Chen T, Redd R, Parmigiani G, Cloughesy TF, Wen PY, Trippa L and Alexander BM: The clinical trials landscape for glioblastoma: is it adequate to develop new treatments? Neuro Oncol 20(8): 1034-1043, 2018. PMID: 29518210. DOI: 10.1093/neuonc/noy027

7 Shergalis A, Bankhead A 3rd, Luesakul U, Muangsin N and Neamati N: Current challenges and opportunities in treating glioblastoma. Pharmacol Rev 70(3): 412-445, 2018. PMID: 29669750. DOI: 10.1124/pr.117.014944

8 Gilbert MR, Dignam JJ, Armstrong TS, Wefel JS, Blumenthal DT, Vogelbaum MA, Colman H, Chakravarti A, Pugh S, Won M, Jeraj R, Brown PD, Jaeckle KA, Schiff D, Stieber VW, Brachman DG, Werner-Wasik M, Tremont-Lukats IW, Sulman EP, Aldape KD, Curran WJ Jr and Mehta MP: A randomized trial of bevacizumab for newly diagnosed glioblastoma. N Engl J Med 370(8): 699-708, 2014. PMID: 24552317. DOI: 10.1056/NEJMoa1308573

9 Neff EP: Cancer modeling thinks big with the pig. Lab Anim (NY) 48(3): 75-78, 2019. PMID: 30742111. DOI: 10.1038/ s41684-019-0246-5

10 Cheon DJ and Orsulic S: Mouse models of cancer. Annu Rev Pathol 6: 95-119, 2011. PMID: 20936938. DOI: 10.1146/ annurev.pathol.3.121806.154244

11 Kersten K, de Visser KE, van Miltenburg MH and Jonkers J: Genetically engineered mouse models in oncology research and cancer medicine. EMBO Mol Med 9(2): 137-153, 2017. PMID: 28028012. DOI: $10.15252 / \mathrm{emmm} .201606857$

12 Rangarajan A and Weinberg RA: Opinion: Comparative biology of mouse versus human cells: modelling human cancer in mice. Nat Rev Cancer 3(12): 952-959, 2003. PMID: 14737125. DOI: $10.1038 / \mathrm{nrc} 1235$

13 Sauleau P, Lapouble E, Val-Laillet D and Malbert CH: The pig model in brain imaging and neurosurgery. Animal 3(8): 1138-1151, 2009. PMID: 22444844. DOI: 10.1017/S1751731109004649

14 Hodge RD, Bakken TE, Miller JA, Smith KA, Barkan ER, Graybuck LT, Close JL, Long B, Johansen N, Penn O, Yao Z, Eggermont J, Höllt T, Levi BP, Shehata SI, Aevermann B, Beller A, Bertagnolli D, Brouner K, Casper T, Cobbs C, Dalley R, Dee N, Ding SL, Ellenbogen RG, Fong O, Garren E, Goldy J, Gwinn RP, Hirschstein D, Keene CD, Keshk M, Ko AL, Lathia K, Mahfouz A, Maltzer Z, McGraw M, Nguyen TN, Nyhus J, Ojemann JG, Oldre A, Parry S, Reynolds S, Rimorin C, Shapovalova NV, Somasundaram S, Szafer A, Thomsen ER, Tieu M, Quon G, Scheuermann RH, Yuste R, Sunkin SM, Lelieveldt B, Feng D, Ng L, Bernard A, Hawrylycz M, Phillips JW, Tasic B, Zeng H, Jones 
AR, Koch C and Lein ES: Conserved cell types with divergent features in human versus mouse cortex. Nature 573(7772): 61-68, 2019. PMID: 31435019. DOI: 10.1038/s41586-019-1506-7

15 Lind NM, Moustgaard A, Jelsing J, Vajta G, Cumming P and Hansen AK: The use of pigs in neuroscience: modeling brain disorders. Neurosci Biobehav Rev 31(5): 728-751, 2007. PMID: 17445892. DOI: 10.1016/j.neubiorev.2007.02.003

16 Al Dahhan NZ, De Felice FG and Munoz DP: Potentials and pitfalls of cross-translational models of cognitive impairment. Front Behav Neurosci 13: 48, 2019. PMID: 30923497. DOI: 10.3389/fnbeh.2019.00048

17 Grone BP and Baraban SC: Animal models in epilepsy research: legacies and new directions. Nat Neurosci 18(3): 339-343, 2015. PMID: 25710835. DOI: 10.1038/nn.3934

18 Watson AL, Carlson DF, Largaespada DA, Hackett PB and Fahrenkrug SC: Engineered Swine Models of Cancer. Front Genet 7: 78, 2016. PMID: 27242889. DOI: 10.3389/ fgene. 2016.00078

19 de Jong M and Maina T: Of mice and humans: are they the same? - Implications in cancer translational research. J Nucl Med 51(4): 501-504, 2010. PMID: 20237033. DOI: 10.2967/jnumed.109.065706

20 van Tellingen $\mathrm{O}$, Yetkin-Arik $\mathrm{B}$, de Gooijer MC, Wesseling $\mathrm{P}$, Wurdinger T and de Vries HE: Overcoming the blood-brain tumor barrier for effective glioblastoma treatment. Drug Resist Updat 19: 1-12, 2015. PMID: 25791797. DOI: 10.1016/j.drup.2015.02.002

21 O'Brown NM, Pfau SJ and Gu C: Bridging barriers: a comparative look at the blood-brain barrier across organisms. Genes Dev 32(7-8): 466-478, 2018. PMID: 29692355. DOI: $10.1101 / \mathrm{gad} .309823 .117$

22 Bohannon DG, Long D and Kim WK: Understanding the heterogeneity of human pericyte subsets in blood-brain barrier homeostasis and neurological diseases. Cells 10(4): 890, 2021. PMID: 33919664. DOI: 10.3390/cells10040890

23 Barone FC, Knudsen DJ, Nelson AH, Feuerstein GZ and Willette RN: Mouse strain differences in susceptibility to cerebral ischemia are related to cerebral vascular anatomy. J Cereb Blood Flow Metab 13(4): 683-692, 1993. PMID: 8314921. DOI: $10.1038 /$ jcbfm. 1993.87

24 Mouse Genome Sequencing Consortium., Waterston RH, LindbladToh K, Birney E, Rogers J, Abril JF, Agarwal P, Agarwala R, Ainscough R, Alexandersson M, An P, Antonarakis SE, Attwood J, Baertsch R, Bailey J, Barlow K, Beck S, Berry E, Birren B, Bloom T, Bork P, Botcherby M, Bray N, Brent MR, Brown DG, Brown SD, Bult C, Burton J, Butler J, Campbell RD, Carninci P, Cawley S, Chiaromonte F, Chinwalla AT, Church DM, Clamp M, Clee C, Collins FS, Cook LL, Copley RR, Coulson A, Couronne O, Cuff J, Curwen V, Cutts T, Daly M, David R, Davies J, Delehaunty KD, Deri J, Dermitzakis ET, Dewey C, Dickens NJ, Diekhans M, Dodge S, Dubchak I, Dunn DM, Eddy SR, Elnitski L, Emes RD, Eswara P, Eyras E, Felsenfeld A, Fewell GA, Flicek P, Foley K, Frankel WN, Fulton LA, Fulton RS, Furey TS, Gage D, Gibbs RA, Glusman G, Gnerre S, Goldman N, Goodstadt L, Grafham D, Graves TA, Green ED, Gregory S, Guigó R, Guyer M, Hardison RC, Haussler D, Hayashizaki Y, Hillier LW, Hinrichs A, Hlavina W, Holzer T, Hsu F, Hua A, Hubbard T, Hunt A, Jackson I, Jaffe DB, Johnson LS, Jones M, Jones TA, Joy A, Kamal M, Karlsson EK, Karolchik D, Kasprzyk A, Kawai J, Keibler E, Kells C, Kent WJ, Kirby A, Kolbe DL, Korf I, Kucherlapati RS, Kulbokas EJ, Kulp D, Landers T, Leger JP, Leonard S, Letunic I, Levine R, Li J,
Li M, Lloyd C, Lucas S, Ma B, Maglott DR, Mardis ER, Matthews L, Mauceli E, Mayer JH, McCarthy M, McCombie WR, McLaren S, McLay K, McPherson JD, Meldrim J, Meredith B, Mesirov JP, Miller W, Miner TL, Mongin E, Montgomery KT, Morgan M, Mott R, Mullikin JC, Muzny DM, Nash WE, Nelson JO, Nhan MN, Nicol R, Ning Z, Nusbaum C, O'Connor MJ, Okazaki Y, Oliver K, Overton-Larty E, Pachter L, Parra G, Pepin KH, Peterson J, Pevzner P, Plumb R, Pohl CS, Poliakov A, Ponce TC, Ponting CP, Potter S, Quail M, Reymond A, Roe BA, Roskin KM, Rubin EM, Rust AG, Santos R, Sapojnikov V, Schultz B, Schultz J, Schwartz MS, Schwartz S, Scott C, Seaman S, Searle S, Sharpe T, Sheridan A, Shownkeen R, Sims S, Singer JB, Slater G, Smit A, Smith DR, Spencer B, Stabenau A, Stange-Thomann N, Sugnet C, Suyama M, Tesler G, Thompson J, Torrents D, Trevaskis E, Tromp J, Ucla C, Ureta-Vidal A, Vinson JP, Von Niederhausern AC, Wade CM, Wall M, Weber RJ, Weiss RB, Wendl MC, West AP, Wetterstrand K, Wheeler R, Whelan S, Wierzbowski J, Willey D, Williams S, Wilson RK, Winter E, Worley KC, Wyman D, Yang S, Yang SP, Zdobnov EM, Zody MC and Lander ES: Initial sequencing and comparative analysis of the mouse genome. Nature 420(6915): 520562, 2002. PMID: 12466850. DOI: 10.1038/nature01262

25 Heyer J, Yang K, Lipkin M, Edelmann W and Kucherlapati R: Mouse models for colorectal cancer. Oncogene 18(38): 53255333, 1999. PMID: 10498885. DOI: 10.1038/sj.onc.1203036

26 Karim BO and Huso DL: Mouse models for colorectal cancer. Am J Cancer Res 3(3): 240-250, 2013. PMID: 23841024.

27 Evers B and Jonkers J: Mouse models of BRCA1 and BRCA2 deficiency: past lessons, current understanding and future prospects. Oncogene 25(43): 5885-5897, 2006. PMID: 16998503. DOI: $10.1038 /$ sj.onc.1209871

28 Stylli SS, Luwor RB, Ware TM, Tan F and Kaye AH: Mouse models of glioma. J Clin Neurosci 22(4): 619-626, 2015. PMID: 25698543. DOI: $10.1016 /$ j.jocn.2014.10.013

29 Miyai M, Tomita H, Soeda A, Yano H, Iwama T and Hara A: Current trends in mouse models of glioblastoma. J Neurooncol 135(3): 423-432, 2017. PMID: 29052807. DOI: 10.1007/s11060017-2626-2

30 Schook LB, Collares TV, Darfour-Oduro KA, De AK, Rund LA, Schachtschneider KM and Seixas FK: Unraveling the swine genome: implications for human health. Annu Rev Anim Biosci 3: 219-244, 2015. PMID: 25689318. DOI: 10.1146/annurevanimal-022114-110815

31 D'Amico RS, Neira JA, Yun J, Alexiades NG, Banu M, Englander ZK, Kennedy BC, Ung TH, Rothrock RJ, Romanov A, Guo X, Zhao B, Sonabend AM, Canoll P and Bruce JN: Validation of an effective implantable pump-infusion system for chronic convection-enhanced delivery of intracerebral topotecan in a large animal model. J Neurosurg: 1-10, 2019. PMID: 31374547. DOI: $10.3171 / 2019.3 . J N S 1963$

32 White E, Woolley M, Bienemann A, Johnson DE, Wyatt M, Murray G, Taylor H and Gill SS: A robust MRI-compatible system to facilitate highly accurate stereotactic administration of therapeutic agents to targets within the brain of a large animal model. J Neurosci Methods 195(1): 78-87, 2011. PMID: 21074564. DOI: 10.1016/j.jneumeth.2010.10.023

33 Herickhoff CD, Wilson CM, Grant GA, Britz GW, Light ED, Palmeri ML, Wolf PD and Smith SW: Dual-mode IVUS transducer for image-guided brain therapy: preliminary experiments. Ultrasound Med Biol 37(10): 1667-1676, 2011. PMID: 21856073. DOI: 10.1016/j.ultrasmedbio.2011.06.017 
34 White E, Bienemann A, Pugh J, Castrique E, Wyatt M, Taylor $\mathrm{H}, \mathrm{Cox} \mathrm{A}, \mathrm{McLeod} \mathrm{C}$ and Gill S: An evaluation of the safety and feasibility of convection-enhanced delivery of carboplatin into the white matter as a potential treatment for high-grade glioma J Neurooncol 108(1): 77-88, 2012. PMID: 22476649. DOI: 10.1007/s11060-012-0833-4

35 LeBlanc AK and Mazcko CN: Improving human cancer therapy through the evaluation of pet dogs. Nat Rev Cancer 20(12): 727742, 2020. PMID: 32934365. DOI: 10.1038/s41568-020-0297-3

36 Rogers J and Gibbs RA: Comparative primate genomics: emerging patterns of genome content and dynamics. Nat Rev Genet 15(5): 347-359, 2014. PMID: 24709753. DOI: $10.1038 / \mathrm{nrg} 3707$

37 Bourneuf E: The MeLiM Minipig: An original spontaneous model to explore cutaneous melanoma genetic basis. Front Genet 8: 146, 2017. PMID: 29081790. DOI: 10.3389/fgene. 2017.00146

38 White KA, Swier VJ, Cain JT, Kohlmeyer JL, Meyerholz DK, Tanas MR, Uthoff J, Hammond E, Li H, Rohret FA, Goeken A, Chan $\mathrm{CH}$, Leidinger MR, Umesalma S, Wallace MR, Dodd RD, Panzer K, Tang AH, Darbro BW, Moutal A, Cai S, Li W, Bellampalli SS, Khanna R, Rogers CS, Sieren JC, Quelle DE and Weimer JM: A porcine model of neurofibromatosis type 1 that mimics the human disease. JCI Insight 3(12): e120402, 2018. PMID: 29925695. DOI: 10.1172/jci.insight.120402

39 Schachtschneider KM, Schwind RM, Darfour-Oduro KA, De AK, Rund LA, Singh K, Principe DR, Guzman G, Ray CE Jr, Ozer H, Gaba RC and Schook LB: A validated, transitional and translational porcine model of hepatocellular carcinoma Oncotarget 8(38): 63620-63634, 2017. PMID: 28969016. DOI: 10.18632 /oncotarget. 18872

40 Flisikowska T, Merkl C, Landmann M, Eser S, Rezaei N, Cui X, Kurome M, Zakhartchenko V, Kessler B, Wieland H, Rottmann O, Schmid RM, Schneider G, Kind A, Wolf E, Saur D and Schnieke A: A porcine model of familial adenomatous polyposis. Gastroenterology 143(5): 1173-1175.e7, 2012. PMID: 22864254. DOI: $10.1053 /$ j.gastro.2012.07.110

41 Groenen MA: A decade of pig genome sequencing: a window on pig domestication and evolution. Genet Sel Evol 48: 23, 2016. PMID: 27025270. DOI: 10.1186/s12711-016-0204-2

42 Schook LB, Collares TV, Hu W, Liang Y, Rodrigues FM, Rund LA, Schachtschneider KM, Seixas FK, Singh K, Wells KD, Walters EM, Prather RS and Counter CM: A genetic porcine model of cancer. PLoS One 10(7): e0128864, 2015. PMID: 26132737. DOI: 10.1371 journal.pone.0128864

43 Humphray SJ, Scott CE, Clark R, Marron B, Bender C, Camm N, Davis J, Jenks A, Noon A, Patel M, Sehra H, Yang F, Rogatcheva MB, Milan D, Chardon P, Rohrer G, Nonneman D, de Jong P, Meyers SN, Archibald A, Beever JE, Schook LB and Rogers J: A high utility integrated map of the pig genome. Genome Biol 8(7): R139, 2007. PMID: 17625002. DOI: 10.1186/gb-2007-8-7-r139

44 Zhang C and Plastow G: Genomic diversity in pig (Sus scrofa) and its comparison with human and other livestock. Curr Genomics 12(2): 138-146, 2011. PMID: 21966252. DOI: $10.2174 / 138920211795564386$

45 Schachtschneider KM, Madsen O, Park C, Rund LA, Groenen MA and Schook LB: Adult porcine genome-wide DNA methylation patterns support pigs as a biomedical model. BMC Genomics 16: 743, 2015. PMID: 26438392. DOI: 10.1186/s12864-015-1938-x
46 Yan S, Tu Z, Liu Z, Fan N, Yang H, Yang S, Yang W, Zhao Y, Ouyang Z, Lai C, Yang H, Li L, Liu Q, Shi H, Xu G, Zhao H, Wei H, Pei Z, Li S, Lai L and Li XJ: A Huntingtin knockin pig model recapitulates features of selective neurodegeneration in Huntington's disease. Cell 173(4): 989-1002.e13, 2018. PMID: 29606351. DOI: 10.1016/j.cell.2018.03.005

47 Selek L, Seigneuret E, Nugue G, Wion D, Nissou MF, Salon C, Seurin MJ, Carozzo C, Ponce F, Roger T and Berger F: Imaging and histological characterization of a human brain xenograft in pig: the first induced glioma model in a large animal. J Neurosci Methods 221: 159-165, 2014. PMID: 24126047. DOI: 10.1016/j.jneumeth.2013.10.002

48 Khoshnevis M, Carozzo C, Bonnefont-Rebeix C, Belluco S, Leveneur O, Chuzel T, Pillet-Michelland E, Dreyfus M, Roger $\mathrm{T}$, Berger F and Ponce F: Development of induced glioblastoma by implantation of a human xenograft in Yucatan minipig as a large animal model. J Neurosci Methods 282: 61-68, 2017. PMID: 28284687. DOI: 10.1016/j.jneumeth.2017.03.007

49 Khoshnevis M, Carozzo C, Brown R, Bardiès M, BonnefontRebeix C, Belluco S, Nennig C, Marcon L, Tillement O, Gehan $\mathrm{H}$, Louis C, Zahi I, Buronfosse T, Roger $\mathrm{T}$ and Ponce F: Feasibility of intratumoral 165 Holmium siloxane delivery to induced U87 glioblastoma in a large animal model, the Yucatan minipig. PLoS One 15(6): e0234772, 2020. PMID: 32555746. DOI: 10.1371 journal.pone .0234772

50 Tora MS, Texakalidis P, Neill S, Wetzel J, Rindler RS, Hardcastle N, Nagarajan PP, Krasnopeyev A, Roach C, James R, Bruce JN, Canoll P, Federici T, Oshinski JN and Boulis NM: Lentiviral vector induced modeling of high-grade spinal cord glioma in minipigs. Sci Rep 10(1): 5291, 2020. PMID: 32210315. DOI: $10.1038 / \mathrm{s} 41598-020-62167-9$

51 Kijima N, Kanemura Y and De Vleeschouwer S: Mouse models of glioblastoma. 2017. PMID: 29251866. DOI: 10.15586/ codon.glioblastoma.2017.ch7

52 Okada S, Vaeteewoottacharn K and Kariya R: Application of highly immunocompromised mice for the establishment of patient-derived xenograft (PDX) models. Cells 8(8): 889, 2019. PMID: 31412684. DOI: 10.3390/cells8080889

53 Längin M, Mayr T, Reichart B, Michel S, Buchholz S, Guethoff S, Dashkevich A, Baehr A, Egerer S, Bauer A, Mihalj M, Panelli A, Issl L, Ying J, Fresch AK, Buttgereit I, Mokelke M, Radan J, Werner F, Lutzmann I, Steen S, Sjöberg T, Paskevicius A, Qiuming L, Sfriso R, Rieben R, Dahlhoff M, Kessler B, Kemter E, Kurome M, Zakhartchenko V, Klett K, Hinkel R, Kupatt C, Falkenau A, Reu S, Ellgass R, Herzog R, Binder U, Wich G, Skerra A, Ayares D, Kind A, Schönmann U, Kaup FJ, Hagl C, Wolf E, Klymiuk N, Brenner P and Abicht JM: Consistent success in life-supporting porcine cardiac xenotransplantation. Nature 564(7736): 430-433, 2018. PMID: 30518863. DOI: 10.1038/s41586-018-0765-Z

54 D'Alessio A, Proietti G, Sica G and Scicchitano BM: Pathological and molecular features of glioblastoma and its peritumoral tissue. Cancers (Basel) 11(4): 469, 2019. PMID: 30987226. DOI: $10.3390 /$ cancers 11040469

55 Gladson CL, Prayson RA and Liu WM: The pathobiology of glioma tumors. Annu Rev Pathol 5: 33-50, 2010. PMID: 19737106. DOI: 10.1146/annurev-pathol-121808-102109

56 Richmond A and Su Y: Mouse xenograft models vs GEM models for human cancer therapeutics. Dis Model Mech 1(2-3): 78-82, 2008. PMID: 19048064. DOI: 10.1242/dmm.000976 
57 Flisikowska T, Kind A and Schnieke A: The new pig on the block: modelling cancer in pigs. Transgenic Res 22(4): 673-680, 2013. PMID: 23748932. DOI: 10.1007/s11248-013-9720-9

58 Scharek L and Tedin K: The porcine immune system - differences compared to man and mouse and possible consequences for infections by Salmonella serovars. Berl Munch Tierarztl Wochenschr 120(7-8): 347-354, 2007. PMID: 17715828.

59 Frese KK and Tuveson DA: Maximizing mouse cancer models. Nat Rev Cancer 7(9): 645-658, 2007. PMID: 17687385. DOI: $10.1038 / \mathrm{nrc} 2192$

60 Dai C, Celestino JC, Okada Y, Louis DN, Fuller GN and Holland EC: PDGF autocrine stimulation dedifferentiates cultured astrocytes and induces oligodendrogliomas and oligoastrocytomas from neural progenitors and astrocytes in vivo. Genes Dev 15(15): 1913-1925, 2001. PMID: 11485986. DOI: 10.1101/gad.903001

61 Massey SC, Rockne RC, Hawkins-Daarud A, Gallaher J, Anderson ARA, Canoll P and Swanson KR: Simulating PDGFdriven glioma growth and invasion in an anatomically accurate brain domain. Bull Math Biol 80(5): 1292-1309, 2018. PMID: 28842831. DOI: $10.1007 / \mathrm{s} 11538-017-0312-3$

62 Marumoto T, Tashiro A, Friedmann-Morvinski D, Scadeng M, Soda Y, Gage FH and Verma IM: Development of a novel mouse glioma model using lentiviral vectors. Nat Med 15(1): 110-116, 2009. PMID: 19122659. DOI: $10.1038 / \mathrm{nm} .1863$

63 Chen R, Smith-Cohn M, Cohen AL and Colman H: Glioma subclassifications and their clinical significance. Neurotherapeutics 14(2): 284-297, 2017. PMID: 28281173. DOI: 10.1007/s13311-017-0519-x

64 Schook LB, Rund L, Begnini KR, Remião MH, Seixas FK and Collares T: Emerging technologies to create inducible and genetically defined porcine cancer models. Front Genet 7: 28, 2016. PMID: 26973698. DOI: 10.3389/fgene.2016.00028

65 Rabotti GF, Grove AS Jr, Sellers RL and Anderson WR: Induction of multiple brain tumours (gliomata and leptomeningeal sarcomata) in dogs by Rous sarcoma virus. Nature 209(5026): 884-886, 1966. PMID: 4288513. DOI: 10.1038/209884a0

66 Salcman M, Scott EW, Schepp RS, Knipp HC and Broadwell RD: Transplantable canine glioma model for use in experimental neuro-oncology. Neurosurgery 11(3): 372-381, 1982. PMID: 6290929. DOI: 10.1227/00006123-198209000-00007

67 Krisht AF, Yoo K, Arnautovic KI and Al-Mefty O: Cavernous sinus tumor model in the canine: a simulation model for cavernous sinus tumor surgery. Neurosurgery 56(6): 1361-5; discussion 1365-6, 2005. PMID: 15918953. DOI:10.1227/01.neu.0000159715.47962.c4

68 LeBlanc A: A report from the NCI comparative brain tumor consortium (CBTC) glioma pathology board: A revised diagnostic classification in support of validation of the canine glioma patient as a model for humans. Vet Pathol 56(4): 642643, 2019. PMID: 30612539. DOI: 10.1177/0300985818819179

69 Candolfi M, Curtin JF, Nichols WS, Muhammad AG, King GD, Pluhar GE, McNiel EA, Ohlfest JR, Freese AB, Moore PF, Lerner $\mathrm{J}$, Lowenstein PR and Castro MG: Intracranial glioblastoma models in preclinical neuro-oncology: neuropathological characterization and tumor progression. J Neurooncol 85(2): 133148, 2007. PMID: 17874037. DOI: 10.1007/s11060-007-9400-9

70 Herranz C, Fernández F, Martín-Ibáñez R, Blasco E, Crespo E, De la Fuente C, Añor S, Rabanal RM, Canals JM and Pumarola M: Spontaneously arising canine glioma as a potential model for human glioma. J Comp Pathol 154(2-3): 169-179, 2016. PMID: 26804204. DOI: 10.1016/j.jcpa.2015.12.001
71 Amin SB, Anderson KJ, Boudreau CE, Martinez-Ledesma E, Kocakavuk E, Johnson KC, Barthel FP, Varn FS, Kassab C, Ling X, Kim H, Barter M, Lau CC, Ngan CY, Chapman M, Koehler JW, Long JP, Miller AD, Miller CR, Porter BF, Rissi DR, Mazcko C, LeBlanc AK, Dickinson PJ, Packer RA, Taylor AR, Rossmeisl JH Jr, Woolard KD, Heimberger AB, Levine JM and Verhaak RGW: Comparative molecular life history of spontaneous canine and human gliomas. Cancer Cell 37(2): 243-257.e7, 2020. PMID: 32049048. DOI: 10.1016/j.ccell.2020.01.004

72 Hubbard ME, Arnold S, Bin Zahid A, McPheeters M, Gerard O'Sullivan M, Tabaran AF, Hunt MA and Pluhar GE: Naturally occurring canine glioma as a model for novel therapeutics. Cancer Invest 36(8): 415-423, 2018. PMID: 30234401. DOI: 10.1080/07357907.2018.1514622

73 Dickinson PJ, LeCouteur RA, Higgins RJ, Bringas JR, Larson RF, Yamashita Y, Krauze MT, Forsayeth J, Noble CO, Drummond DC, Kirpotin DB, Park JW, Berger MS and Bankiewicz KS: Canine spontaneous glioma: a translational model system for convection-enhanced delivery. Neuro Oncol 12(9): 928-940, 2010. PMID: 20488958. DOI: 10.1093/neuonc/noq046

74 MacDiarmid JA, Langova V, Bailey D, Pattison ST, Pattison SL, Christensen N, Armstrong LR, Brahmbhatt VN, Smolarczyk K, Harrison MT, Costa M, Mugridge NB, Sedliarou I, Grimes NA, Kiss DL, Stillman B, Hann CL, Gallia GL, Graham RM and Brahmbhatt H: Targeted doxorubicin delivery to brain tumors via minicells: Proof of principle using dogs with spontaneously occurring tumors as a model. PLoS One 11(4): e0151832, 2016. PMID: 27050167. DOI: 10.1371/journal.pone.0151832

75 Jain KK: A critical overview of targeted therapies for glioblastoma. Front Oncol 8: 419, 2018. PMID: 30374421. DOI: 10.3389/fonc.2018.00419

76 Yaghi NK, Wei J, Hashimoto Y, Kong LY, Gabrusiewicz K, Nduom EK, Ling X, Huang N, Zhou S, Kerrigan BC, Levine JM, Fajt VR, Levine G, Porter BF, Marcusson EG, Tachikawa K, Chivukula P, Webb DC, Payne JE and Heimberger AB: Immune modulatory nanoparticle therapeutics for intracerebral glioma. Neuro Oncol 19(3): 372-382, 2017. PMID: 27765835. DOI: 10.1093/neuonc/now198

77 Bentley RT, Ahmed AU, Yanke AB, Cohen-Gadol AA and Dey M: Dogs are man's best friend: in sickness and in health. Neuro Oncol 19(3): 312-322, 2017. PMID: 27298310. DOI: 10.1093/ neuonc/now 109

78 Filley A, Henriquez M, Bhowmik T, Tewari BN, Rao X, Wan J, Miller MA, Liu Y, Bentley RT and Dey M: Immunologic and gene expression profiles of spontaneous canine oligodendrogliomas. J Neurooncol 137(3): 469-479, 2018. PMID: 29330750. DOI: $10.1007 / \mathrm{s} 11060-018-2753-4$

79 Kimmelman J and Nalbantoglu J: Faithful companions: a proposal for neurooncology trials in pet dogs. Cancer Res 67(10): 4541-4544, 2007. PMID: 17510377. DOI: $10.1158 /$ 0008-5472.CAN-06-3792

80 Bentley RT, Thomovsky SA, Miller MA, Knapp DW and Cohen-Gadol AA: Canine (Pet Dog) tumor microsurgery and intratumoral concentration and safety of metronomic chlorambucil for spontaneous glioma: A phase I clinical trial. World Neurosurg 116: e534-e542, 2018. PMID: 29775768. DOI: $10.1016 /$ j.wneu.2018.05.027

81 Rhesus Macaque Genome Sequencing and Analysis Consortium, Gibbs RA, Rogers J, Katze MG, Bumgarner R, Weinstock GM, Mardis ER, Remington KA, Strausberg RL, Venter JC, Wilson 
RK, Batzer MA, Bustamante CD, Eichler EE, Hahn MW, Hardison RC, Makova KD, Miller W, Milosavljevic A, Palermo RE, Siepel A, Sikela JM, Attaway T, Bell S, Bernard KE, Buhay CJ, Chandrabose MN, Dao M, Davis C, Delehaunty KD, Ding Y, Dinh HH, Dugan-Rocha S, Fulton LA, Gabisi RA, Garner TT, Godfrey J, Hawes AC, Hernandez J, Hines S, Holder M, Hume J, Jhangiani SN, Joshi V, Khan ZM, Kirkness EF, Cree A, Fowler RG, Lee S, Lewis LR, Li Z, Liu YS, Moore SM, Muzny D, Nazareth LV, Ngo DN, Okwuonu GO, Pai G, Parker D, Paul HA, Pfannkoch C, Pohl CS, Rogers YH, Ruiz SJ, Sabo A, Santibanez J, Schneider BW, Smith SM, Sodergren E, Svatek AF, Utterback TR, Vattathil S, Warren W, White CS, Chinwalla AT, Feng Y, Halpern AL, Hillier LW, Huang X, Minx P, Nelson JO, Pepin KH, Qin X, Sutton GG, Venter E, Walenz BP, Wallis JW, Worley KC, Yang SP, Jones SM, Marra MA, Rocchi M, Schein JE, Baertsch R, Clarke L, Csürös M, Glasscock J, Harris RA, Havlak P, Jackson AR, Jiang H, Liu Y, Messina DN, Shen Y, Song HX, Wylie T, Zhang L, Birney E, Han K, Konkel MK, Lee J, Smit AF, Ullmer B, Wang H, Xing J, Burhans R, Cheng Z, Karro JE, Ma J, Raney B, She X, Cox MJ, Demuth JP, Dumas LJ, Han SG, Hopkins J, Karimpour-Fard A, Kim YH, Pollack JR, Vinar T, Addo-Quaye C, Degenhardt J, Denby A, Hubisz MJ, Indap A, Kosiol C, Lahn BT, Lawson HA, Marklein A, Nielsen R, Vallender EJ, Clark AG, Ferguson B, Hernandez RD, Hirani K, Kehrer-Sawatzki H, Kolb J, Patil S, Pu LL, Ren Y, Smith DG, Wheeler DA, Schenck I, Ball EV, Chen R, Cooper DN, Giardine B, Hsu F, Kent WJ, Lesk A, Nelson DL, O'brien WE, Prüfer K, Stenson PD, Wallace JC, Ke H, Liu XM, Wang P, Xiang AP, Yang F, Barber GP, Haussler D, Karolchik D, Kern AD, Kuhn RM, Smith KE and Zwieg AS: Evolutionary and biomedical insights from the rhesus macaque genome. Science 316(5822): 222-234, 2007. PMID: 17431167. DOI: 10.1126/science.1139247

82 Lowenstine L: Neoplasms and proliferative disorders in nonhuman primates. Primates: $781-814,2021$. DOI: $10.1007 /$ 978-1-4612-4918-4_53

83 McClure HM: Neoplastic disease in non-human primates: Literature review and observation in an autopsy series of 2176 animals. In: The comparative pathology of zoo animals. Montali RJ, Migaki G. (eds.). Smithsonian Institution Press: Washington, DC, pp. 549-565, 1980.

84 Simmons HA and Mattison JA: The incidence of spontaneous neoplasia in two populations of captive rhesus macaques (Macaca mulatta). Antioxid Redox Signal 14(2): 221-227, 2011. PMID: 20524847. DOI: 10.1089/ars.2010.3311

85 Remick AK, Van Wettere AJ and Williams CV: Neoplasia in prosimians: case series from a captive prosimian population and literature review. Vet Pathol 46(4): 746-772, 2009. PMID: 19276064. DOI: 10.1354/vp.08-VP-0154-R-FL

86 Lonser RR, Walbridge S, Vortmeyer AO, Pack SD, Nguyen TT, Gogate N, Olson JJ, Akbasak A, Bobo RH, Goffman T, Zhuang $\mathrm{Z}$ and Oldfield EH: Induction of glioblastoma multiforme in nonhuman primates after therapeutic doses of fractionated whole-brain radiation therapy. J Neurosurg 97(6): 1378-1389, 2002. PMID: 12507137. DOI: 10.3171/jns.2002.97.6.1378
87 Lubensky IA, Vortmeyer AO, Kim S, Lonser RR, Park DM, Ikejiri B, Li J, Okamoto H, Walbridge S, Ryschkewitsch C, Major E, Oldfield EH and Zhuang Z: Identification of tumor precursor cells in the brains of primates with radiation-induced de novo glioblastoma multiforme. Cell Cycle 5(4): 452-456, 2006. PMID: 16479164. DOI: $10.4161 /$ cc.5.4.2482

88 Rodgers LT, Lester McCully CM, Odabas A, Cruz R, Peer CJ, Figg WD and Warren KE: Characterizing the pharmacokinetics of panobinostat in a non-human primate model for the treatment of diffuse intrinsic pontine glioma. Cancer Chemother Pharmacol 85(4): 827-830, 2020. PMID: 31894347. DOI: 10.1007/s00280-019-04021-y

89 Tong Y, Hao J, Tu Q, Yu H, Yan L, Li Y, Lv L, Wang F, Iavarone A and Zhao X: A tree shrew glioblastoma model recapitulates features of human glioblastoma. Oncotarget 8(11): 17897-17907, 2017. PMID: 28199986. DOI: 10.18632/oncotarget.15225

90 Lin J, Chen G, Gu L, Shen Y, Zheng M, Zheng W, Hu X, Zhang X, Qiu Y, Liu X and Jiang C: Phylogenetic affinity of tree shrews to Glires is attributed to fast evolution rate. Mol Phylogenet Evol 71: 193-200, 2014. PMID: 24333622. DOI: 10.1016/j.ympev.2013.12.001

$91 \mathrm{Xu}$ L, Chen SY, Nie WH, Jiang XL and Yao YG: Evaluating the phylogenetic position of Chinese tree shrew (Tupaia belangeri chinensis) based on complete mitochondrial genome: implication for using tree shrew as an alternative experimental animal to primates in biomedical research. J Genet Genomics 39(3): 131137, 2012. PMID: 22464472. DOI: 10.1016/j.jgg.2012.02.003

92 Carvalho C, Gaspar A, Knight A and Vicente L: Ethical and scientific pitfalls concerning laboratory research with non-human primates, and possible solutions. Animals (Basel) 9(1): 12, 2018. PMID: 30597951. DOI: 10.3390/ani9010012

93 Lankau EW, Turner PV, Mullan RJ and Galland GG: Use of nonhuman primates in research in North America. J Am Assoc Lab Anim Sci 53(3): 278-282, 2014. PMID: 24827570.

94 European Commission: Seventh Report on the Statistics on the Number of Animals Used for Experimental and Other Scientific Purposes in the Member States of the European Union. 2013. Available at: https://eur-lex.europa.eu/legal-content/EN/TXT/? uri=CELEX:52013DC0859 [Last accessed on September 17, 2021]

95 Feng G, Jensen FE, Greely HT, Okano H, Treue S, Roberts AC, Fox JG, Caddick S, Poo MM, Newsome WT and Morrison JH: Opportunities and limitations of genetically modified nonhuman primate models for neuroscience research. Proc Natl Acad Sci USA 117(39): 24022-24031, 2020. PMID: 32817435. DOI: $10.1073 /$ pnas. 2006515117
Received September 7, 2021

Revised September 25, 2021

Accepted September 29, 2021 